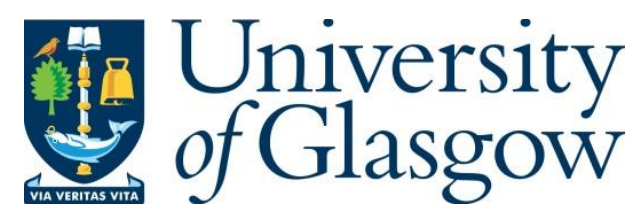

Souleimanov, E. A. and Aliyev, H. (2015) Asymmetry of values, indigenous forces, and incumbent success in counterinsurgency: evidence from Chechnya. Journal of Strategic Studies, 38(5), pp. 678-703.

There may be differences between this version and the published version. You are advised to consult the publisher's version if you wish to cite from it.

http://eprints.gla.ac.uk/153385/

Deposited on: 11 December 2017

Enlighten - Research publications by members of the University of Glasgow http://eprints.gla.ac.uk 


\title{
Asymmetry of Values, Indigenous Forces, and Incumbent Success in Counterinsurgency: Evidence from Chechnya
}

\begin{abstract}
This article fills the gap in existing scholarship on asymmetric conflict, indigenous forces, and how socio-cultural codes shape the dynamics and outcomes of conflict transformation. Specifically, it identifies three key socio-cultural values commonplace in honorific societies: retaliation, hospitality, and silence. As sources of effective pro-insurgent violent mobilisation and support from among the local population, these values provide insurgents with an asymmetric advantage over much stronger incumbents. Using the case studies of the two Russian counterinsurgencies in Chechnya, the article shows the mechanisms on the ground through which Moscow's deployment of indigenous forces against insurgents helped to stem the tide of conflict, reversing the insurgents' initial advantage in terms of asymmetry of values.
\end{abstract}

Keywords: asymmetry of values, asymmetric conflict, indigenous forces, counterinsurgency, Chechnya, North Caucasus

\section{Introduction}

Throughout history, indigenous forces (IF) have frequently been deployed by the incumbent powers to assist in fighting insurgencies. Over the past thirty years, a large and rapidly growing literature on IF in counterinsurgencies (COIN) has sought to demonstrate 
that the use of IF contributes to the incumbent's success in local conflicts. Studies on the deployment of native units in COIN operations in Vietnam, Malaya, Afghanistan, and many other parts of the world have shown that well-trained, effectively organised, and highly motivated IF provide significant support to incumbents. ${ }^{1}$ IF provide the counterinsurgency with crucial insider information about the insurgents and their supporters, and foster a vital social base among the local population. ${ }^{2}$ IF not only help the incumbent to increase its numbers, but also to legitimise its efforts in the eyes of the local populace and beyond. ${ }^{3}$

While many have studied the importance of deploying IF in COIN, little is known about the particular mechanisms allowing IF to contribute to a successful COIN. For example, it is still unclear as to how, and under what conditions, the deployment of IF contributes to a stronger incumbent's victory over a weaker insurgent. Existing literature identifies the following key factors contributing to the successful deployment of IF in COIN: military training; combat experience; an ideological or material motivational base;

\footnotetext{
Robert M. Cassidy, 'Regular and Irregular Indigenous Forces for a Long Irregular War', The RUSI Journal, 152 /1 (2007) 42-47; James S. Corum, Training Indigenous Forces in Counterinsurgency: A Tale of Two Insurgencies (Pennsylvania: Strategic Studies Institute 2006). 2 Corum, Training Indigenous Forces; Robert M. Cassidy, 'The Long Small War: Indigenous Forces for Counterinsurgency', Parameters (2006) 47-62; Yoav Gortzak, 'Using Indigenous Forces in Counterinsurgency Operations: The French in Algeria, 1954-1962‘, Journal of Strategic Studies, 32/2 (2009) 307-333.

3 Cassidy, The Long Small War, 47-48.
} 
strong command and control; and the incumbent's understanding of local social microcosms. $^{4}$

This article complements the existing literature by arguing that, in addition to the aforementioned factors responsible for the effectiveness of IF, specific socio-cultural values form a unique set of mechanisms. These socio-cultural codes create an asymmetry of values between insurgents and the incumbent in favour of the former, providing them with mechanisms of violent mobilisation and support structures to undermine this valuebased imbalance. Although extensive research has been conducted on political, economic, and ideological motivations of insurgent combatants, researchers have not addressed the effects of socio-cultural values on conflict dynamics and outcomes in great detail. In addition to economic, political, and other ideological considerations, it is their reliance on these value systems that enables insurgents to succeed in defeating their adversaries' will to continue fighting.

This article argues that the use of IF helps the incumbent to balance the asymmetry of values in its favour, shaping conflict transformation and affecting its outcome. Using the examples of two successive Russian counterinsurgency campaigns in Chechnya, this article demonstrates that: (1) retaliation, as well as the codes of silence and hospitality, provide both a robust impetus for violent mobilisation and serve as insurgent support structures, and that (2) IF are able to transform a conflict's dynamics by offsetting the asymmetry of values previously existing among the belligerents in favour of the incumbent. This article thus answers the questions: Does the deployment of IF

\footnotetext{
$4 \quad$ Gortzak, Using Indigenous Forces, 329-331.
} 
affect the imbalance of socio-cultural codes? How and under what conditions does the use of IF contribute to the incumbent's success in an asymmetric conflict?

This research follows a case study design based on an in-depth comparative analysis of both primary qualitative interview data and secondary sources. The bulk of primary interview data utilised in this article was collected during a series of 32 face-toface interviews conducted in major European cities with two categories of informants. First, in-depth semi-structured interviews were conducted with former and current members of Chechen insurgent groups. Due to security concerns, this category of participants was interviewed under the condition of strict confidentiality. The second category of interviewees includes experts, scholars, and practitioners with relevant work or research experience.

\section{Theoretical framework: Asymmetric conflicts}

While disparity in numbers, weapons, military strategy, and ideology has existed throughout human history, it is only after the start of the Cold War, and more recently with the development of 'new wars' fought between regular armies and insurgents, that the concept of asymmetric warfare has been firmly established in literature on conflict studies. ${ }^{5}$ With the increase in the number of 'new wars' and the decreasing occurrence of 'old wars', i.e. armed conflicts between nation-states, the issue of asymmetry has become

5 Mary Kaldor, New and Old Wars. Organized Violence in a Global Era (Cambridge: Polity Press 2006). 
increasingly important both in academic research and expert reports. ${ }^{6}$ The majority of research on asymmetric conflicts has continuously prioritised the significance of military strength, i.e. technology, training, and preparedness - the typical determinants of military success in classic theories of warfare. ${ }^{7}$

After the U.S. military's failure in the Vietnam War and following the Soviet debacle in Afghanistan, studies on asymmetric conflicts started to emphasise the importance of military strategy. ${ }^{8}$ As argued by Cassidy, ${ }^{9}$ unlike incumbents who faced no direct threat to their existence in fighting insurgencies, for insurgents, the struggle could only mean 'victory or death. ${ }^{10}$ To effectively confront an insurgent force skilled in unconventional warfare, a modern army thus had to re-think its strategy and adapt to a completely different type of combatant - guerrilla fighters. Regardless of the importance of strategic adaptation in modern asymmetric conflicts, it has become readily apparent that a 'weaker' side may overcome its stronger opponents due not only to their reliance on guerrilla tactics, but also to their motivation and will to succeed.

6 T.V. Paul, Asymmetric Conflicts: War Initiation by Weaker Powers (Cambridge: Cambridge University Press 1994); Colin S. Gray, 'Thinking Asymmetrically in Times of Terror', Parameters (Spring 2002) 5-14.

$7 \quad$ Paul, Asymmetric Conflicts.

$8 \quad$ Cassidy, Regular and Irregular, 42-43.

9 Robert M. Cassidy, 'Why Great Powers Fight Small Wars Badly', Military Review 10-11 (2000) 41-53.

$10 \quad$ Ibid. 44. 
This has led to the expansion of the literature on motivational asymmetry. Pioneered by Mack, ${ }^{11}$ who noted that it is only possible for insurgents to win if they succeed in breaking their adversaries' will to continue fighting, the literature on motivational asymmetry has focused on the incentives and will of the warring sides. Although most of the early interpretations of asymmetric conflicts have focused almost entirely on military and economic aspects of the warring sides, motivational asymmetry began to attract more followers by the end of the Cold War. ${ }^{12}$ For example, Fischerkeller ${ }^{13}$ introduced the concept of cultural asymmetry - an attempt to distinguish adversaries on the basis of their military culture. Unlike Fischerkeller, who sought primarily to emphasise political aspects of motivational asymmetry in conflicts among nation-states, more recent studies have focused on motivational asymmetry of combatants in COIN operations and other forms of irregular armed conflicts. ${ }^{14}$ Among these, studies by Gross, Winter and van Baarda, and Verweij discuss non-material types of asymmetry from a variety of perspectives. ${ }^{15}$ Merom's ${ }^{16}$ research on motivational asymmetry and the

11 Andrew Mack, "Why Big Nations Lose Small Wars: The Politics of Asymmetric Conflict', World Politics 27/1 (1975).

12 The interest in motivational asymmetry began to increase following the Vietnam War.

13 Michael P. Fischerkeller, 'David versus Goliath: Cultural judgments in asymmetric wars', Security Studies 7/4 (1998) 1-43.

14 Robert M. Cassidy, Russia in Afghanistan and Chechnya: Military Strategic Culture and the Paradoxes of Asymmetric Conflict (Strategic Studies Institute 1993).

15 Michael L. Gross, Moral Dilemmas of Modern War: Torture, Assassination and Blackmail in an Age of Asymmetric Conflict (NY: Cambridge University Press 2010); Yves Winter, 'The Asymmetric War Discourse and its Moral Economies: A Critique', International 
'balance of will' is far more comprehensive; echoing Mack's assumptions and arguing that if a failure to achieve victory usually results in an incumbent's physical withdrawal from a conflict zone and re-definition of its foreign policy, defeat leads to an 'underdog's' complete annihilation. Accordingly, patriotism, nationalism, or the simple desires to protect one's home, household, or lifestyle are often combined with material incentives, political ideology, and religious beliefs. Most of these motivations fall into the category of 'greed' and 'grievance' 17 causes of individual violent mobilisation. Nevertheless, as proven by Merom, motivational and will-centred aspects of violent mobilisation do not always offer a comprehensive explanation as to why incumbents lose 'small wars.' As a matter of fact, asymmetry of motivations and will is a fairly unstable variable that tends to fluctuate under the influence of numerous determinants. For instance, regardless of the religious, political, and patriotic motivations of Pashtun fighters supporting the Taliban on the eve of the allied invasion in 2001, numerous Pashtun tribes soon switched sides and joined a stronger Northern Alliance-led force. ${ }^{18}$ Similarly, the political motivations of Colombia's FARC guerrillas have failed to prevent

Theory 3/3 (2011) 488-514; Th.A. van Baarda and D.E.M. Verweij (eds.) The Moral Dimension of Asymmetrical Warfare. Counter-terrorism, Democratic Values and Military Ethics (Leiden: Martinus Nijhof 2009).

16 Gil Merom, How Democracies Lose Small Wars. State, Society and the Failures of France in Algeria, Israel in Lebanon and the United States in Vietnam (Cambridge: Cambridge University Press 2003).

17 Karen Ballentine and Jake Sherman, The Political Economy of Armed Conflict: Beyond Greed and Grievance (Boulder: Lynne Rienner 2003).

18 John Alexander, “'Decomposing” an Insurgency', The RUSI Journal 157/4 (2012) 48-54. 
continuous mass de-mobilisation and the surrender of rebel fighters. ${ }^{19}$ As most of the research on non-material forms of asymmetry focuses on ideational and motivational dimensions of asymmetric relations, little is known about socio-cultural forms of asymmetry.

\section{Introducing the asymmetry of values}

In order to explain the crucial role of IF in COIN, it is important to understand which factors increase the advantages of indigenous forces, insurgents, and pro-incumbent IF over conventional militaries. This study argues that, along with the previously noted temporary incentives rooted in motivation and ideology, there are also largely permanent socio-cultural codes that influence a conflict's dynamics. Despite occasional attempts to capture social values under diverse collective definitions, ${ }^{20}$ the literature on asymmetric conflicts thus far contains no references to socio-cultural values. These values, consisting of specific socio-cultural codes, such as codes of retaliation, warrior ethos, codes of silence, and systemic hospitality are utilised by honorific societies ${ }^{21}$ as mechanisms of violent mobilisation and support structures in conflict environments. This phenomenon is

19 Kimberly Theidon, 'Transitional Subjects: The Disarmament, Demobilisation and Reintegration of Former Combatants in Colombia', The International Journal of Transitional Justice 1 (2007) 66-90.

20 David L. Buffaloe, 'Defining Asymmetric Warfare', The Land Warfare Papers 58/09 (2006) 22-24.

21 Richard E. Nisbett and Dov Cohen, Culture of Honor. The Psychology of Violence in the South (Boulder: Westview Press 1996). 
highlighted by Alexander's ${ }^{22}$ example of Taliban militants in present-day Afghanistan, noting that ' 80 percent of Afghan insurgents are fighting close to their homes because of grievances felt locally and are not Taliban ideologues.' As many such militants lack political or other ideological motivations, Kilcullen ${ }^{23}$ has designated such fighters motivated by socio-cultural values as 'accidental guerrillas.' Widespread and deeply rooted in the social structures of many 'honour cultures', these socio-cultural codes are normally absent in modern 'industrialised societies.' In conflict environments, these socio-cultural values create a clear-cut disparity between insurgents and the incumbents.

While scholars have emphasised the importance of socio-cultural codes in conflict escalation and transformation in different COIN operations around the world, ${ }^{24}$ the literature has thus far failed to conceptualise and explore this form of asymmetry in detail. This section identifies key authors and pieces of empirical research advancing the literature on socio-cultural codes. For example, Kilcullen, Miakhel and Dorronsoro, and Lobato ${ }^{25}$ have explored the importance of honour-based retaliation and warrior ethos as sources of violent mobilisation, as well as of the code of hospitality in present-day 22 Alexander, "Decomposing” an Insurgency, 50.

23 David Kilcullen, An Accidental Guerilla. Fighting Small Wars in the midst of a Big One (Oxford: Oxford University Press 2009)

24 Robert M. Cassidy, 'Back to the Street without Joy: Counterinsurgency Lessons from Vietnam and Other Small Wars', Parameters (2004) 73-83.

25 Kilcullen, An Accidental Guerilla; Shahmahmood Miakhel, Understanding Afghanistan:

The Importance of Tribal Culture and Structure in Security and Governance (US Institute of Peace 2009); Gilles Dorronsoro and Chantal Lobato, 'The Militia in Afghanistan', Central Asian Survey 8/4 (1989) 95-108. 
Afghanistan. Mohamed has written about honour-centred traditional codes in Somalia, while Boehm and Boyle have studied the characteristics of blood revenge and other forms of honour-based retaliation in Montenegro and Kosovo. ${ }^{26}$ A study by Abu-Lughod explored the characteristics of revenge-centred violent mobilisation among the Bedoin Arab tribes, and Simon ${ }^{27}$ explored socio-cultural values of tribes in Oceania. Gould and Bell have studied the tradition of revenge and the code of silence (omertà) in Italy, and Ikegami has researched honorific codes of blood feud in Samurai-era Japan. ${ }^{28}$ Souleimanov's research has shed light on codes of retaliation and hospitality in conflict-

26 Jama Mohamed, 'Kinship and Contract in Somali Politics', Africa 77/02 (May 2007) 226-249; Christopher Boehm, Blood Revenge. The Enactment and Management of Conflict in Montenegro and other tribal societies (Lawrence: University Press of Kansas 1984); Michael J. Boyle, 'Revenge and reprisal violence in Kosovo', Conflict, Security \& Development 10/2, (2010) 189-216.

27 Lila Abu-Lughod, 'Honor and the Sentiments of Loss in a Bedouin Society', American Ethnologist 12/2 (1985) 245-261; Scott Simon, 'Politics and Headhunting among the Formosan Sejiq: Ethnohistorical Perspectives', Oceania 82/2 (2012) 164-185.

28 Roger V. Gould, 'Revenge as Sanction and Solidarity Display: An Analysis of Vendettas in Nineteenth-Century Corsica', American Sociological Review $65 / 5$ (2000) 682-704; Rudolph Bell, Fate, Honor, Family and Village. Demographic and Cultural Change in Rural Italy since 1800 (Chicago: Chicago University Press 2009); Eiko Ikegami, The Taming of the Samurai: Honorific Individualism and the Making of Modern Japan (Cambridge: Harvard University Press 1995). 
ridden Chechen society in the North Caucasus. ${ }^{29}$ This voluminous literature on sociocultural values as forms of violent mobilisation and support structures demonstrates that, within the context of contemporary conflicts, the reliance on socio-cultural codes creates an asymmetry between the indigenous 'honour cultures' and their opponents from ‘industrialised' societies.

This asymmetric relationship, however, has yet to be applied to research on asymmetric conflicts. The role of socio-cultural values in existing scholarship on asymmetric conflicts has thus far been addressed by two strands of literature. First, a small but growing number of studies on post-heroic warfare have sought to prioritise the importance of honour and other honorific values in the formation of ideational and motivational incentives for violent mobilisation in contemporary conflicts. According to studies by Luttwak and Kober, ${ }^{30}$ the post-WWII militaries of industrialised nations have lost the pre-modern notions of honour, duty, and self-sacrifice, which they have chosen to substitute with modern military technology employed to reduce human losses and to decrease the costs of military campaigns. This research, however, is centred on military traditions rather than on the socio-cultural values of societies impacted by conflicts.

29 Emil Souleimanov, 'The Caucasus Emirate: Genealogy of an Islamist Insurgency', Middle East Policy 18/4 (2011) 55-168.

30 Edward N. Luttwak, 'Toward Post-Heroic Warfare', Foreign Affairs (May/June 1995); Avi Kober, 'From Heroic to Postheroic Warfare: Israel's Way of War in Asymmetrical Conflicts', Armed Forces \& Society 0 (2013) 1-27. 
Second, the role of culture and social traditions is prominent in studies on 'hearts and minds' strategy and other similar population-centric elements of COIN operations. ${ }^{31}$ This strand of literature, in spite of its emphasis on the importance of understanding the local culture and social traditions for incumbents, remains focused on military strategy designed 'to gain the acquiescence of the local population, and therefore prevent the insurgent from gaining popular support. ${ }^{32}$ Specific socio-cultural codes are therefore seen by proponents of 'hearts and minds' strategy as merely parts of indigenous culture and not as mechanisms of violent mobilisation of insurgents (retaliation) and support structures (codes of silence and hospitality). As the central focus of the 'hearts and minds' policy is to address 'popularly held grievances, ${ }^{33}$ the main goal is to remedy the outcomes of asymmetry of values rather than deal with its causes - the disparity in sociocultural values between insurgents and incumbents. In other words, the key challenge for 'hearts and minds' strategists is to change local populations' ideological motivations.

In contrast to motivation- and ideology-centred forms of asymmetry, the asymmetry of values is a socio-anthropological phenomenon engrained in static, socioculturally encoded values that cannot easily change due to political, economic, or even religious milieu. These values, embedded within individuals' socio-cultural attitudes and 31 Robert M. Cassidy, 'Counterinsurgency and Military Culture: State Regulars versus Non-State Irregulars', Baltic Security \& Defence Review 10 (2008) 53-85.

32 Charles Lister, 'Cultural Awareness and Counterinsurgency in Afghanistan', EInternational Relations 11 (2011) 2.

33 Eli Berman, Jacob N. Shapiro and Joseph H. Felter, 'Can Hearts and Minds Be Bought? The Economics of Counterinsurgency in Iraq', Journal of Political Economy 119/4 (2011) 766$819,771$. 
behaviours and sustained and reinforced by public opinion, are based on moral obligation and honorific duty. For instance, the obligation to retaliate for a personal offence or for an offence to one's family is sacred among the Pashtun tribes of Afghanistan, as is the code of hospitality that necessitates protecting guests at any cost. ${ }^{34}$ In the Pashtun culture, as well as among Somali tribes, different ethnic groups of Oceania, North Albanian clans, Vainakh clans of the North Caucasus, and other ethnic groups, the failure to avenge is unacceptable for an individual and may result in the social exclusion and shaming of an entire family or clan. This obligation is passed on over generations and, as described by Miakhel, '[a] son, grandson, great grandson or a cousin can take his revenge even after several generations. ${ }^{35}$ Given the strict adherence to these socio-cultural codes, numerous individuals participate in conflicts either without having particular political allegiances or in spite of them. As demonstrated by Kilcullen, the warrior ethos is deeply engrained in the minds of many Afghans, as a result of which indigenous combatants may choose to join in skirmishes between the Taliban and foreign troops only for the sake of participation. ${ }^{36}$ Therefore, unlike ideological (political and religious) and practical (greed-driven and defensive) motivations, socio-cultural codes are not susceptible to easy change, transformation, or disappearance over the course of a conflict.

Out of the various socio-cultural codes governing the day-to-day lives of honorific societies, this study focuses on three in particular. The first of these is the code of retaliation, based on a socially engrained, honorific custom of blood revenge,

\footnotetext{
$34 \quad$ Miakhel, Understanding Afghanistan, 6.

35 Ibid.

36 Kilcullen, An Accidental Guerilla, 39-41.
} 
implemented in retribution for physical or moral damage incurred by one's family or clan members. The code of retaliation is a powerful mechanism of violent mobilisation, which, according to Nivette, 'is an essential ... tool of social organisation in places with weak socioeconomic ties and political structure. ${ }^{37}$ Although, as stated by Nivette, the code of retaliation is permanently present in the cultural traditions of over 40 different societies around the world, ${ }^{38}$ it is during times of conflict that it transforms into a mechanism of violent mobilisation. In particular, acts of indiscriminate violence frequently committed during modern conflicts, including but not limited to bombing of civilian settlements and mass executions, result in en masse retaliation-driven violent mobilisation of individuals.

The codes of silence and hospitality are two other socio-cultural codes falling under the umbrella concept of asymmetry of values. Essential social components, both in peacetime and during conflict, these two codes function as effective support structures for indigenous combatants mobilised against a foreign occupying force. Intrinsic to many honorific societies, the code of silence serves as a mechanism preventing the local population from providing any sort of information about locals to an outsider. Equally pervasive is the code of hospitality, which dictates that hosts are obliged to shelter and protect their guests at any cost. In times of war, the code of hospitality also requires local populations to offer shelter and protection to local fighters from the same kinship group, clan, or tribe.

37 Amy Nivette, 'Violence in Non-State Societies. A Review', British Journal of

Criminology 51 (2011) 578-598, 586.

$38 \quad$ Ibid. 585. 
To sum up, this paper argues that these three socio-cultural codes embedded in broader socio-cultural value systems intrinsic to numerous honorific societies function as mechanisms shaping conflict transformation and affecting its outcome. These mechanisms, immune to external political or economic incentives offered by incumbents as part of 'hearts and minds' strategy, continuously supply insurgents with the manpower and material support vital to any insurgency. Having presented the role of socio-cultural values in establishing an asymmetric relationship between insurgents and counterinsurgents, the next task is to provide a theoretical explanation of how this form of asymmetry can be undermined by the deployment of IF.

\section{IF in asymmetric conflicts}

From Afghanistan to Somalia, recent Western military interventions have implicitly shown that the asymmetry of values between local insurgents and the incumbents from postmodern societies is often difficult to overcome. Despite the rich experience of COIN, technological superiority, and numerical advantages, stronger incumbents frequently suffer defeats at the hands of their poorly trained and less technologically advanced indigenous opponents. Studies by Merom and Arreguin-Toft present a vivid description of how incumbents fail to succeed in asymmetric conflicts with much weaker enemies. ${ }^{39}$ The French failure to put down the nationalist uprising in Algeria (1954-62), Israel's invasion of Lebanon (1982-85), the American invasion of Vietnam (1965-73), and the Soviet incursion into Afghanistan (1979-89) are among the most well-known examples

39 Merom, How Democracies Lose Small Wars; Ivan Arrequin-Toft, 'How the Weak Win Wars. A Theory of Asymmetric Conflict', International Security 26/1 (2001) 93-128. 
of how modern armies have been unable to succeed in conflicts with weaker local adversaries.

In contrast to the existing literature and in line with the aforementioned arguments on the asymmetry of values, we argue that the deployment of IF can alert the imbalance of values among combatants. The research on the use of IF in asymmetric conflicts is rife with examples of both successful and failed deployments of local forces. ${ }^{40}$ While no study has yet specifically investigated the correlation between IF and asymmetric values, the literature on the use of IF in asymmetric wars suggests that the deployment of IF is far more controversial in conflicts between opponents with disparities in socio-cultural values. For instance, the use of local militia units in post-Taliban Afghanistan 'produced unforeseen and largely deleterious outcomes. ${ }^{41}$ Similarly dubious outcomes have been observed by Dorronsoro and Lobato regarding the use of local Afghan units during the Soviet occupation of Afghanistan. ${ }^{42}$ Due to the marginal role of local forces, the deployment of IF against Sunni tribes in Iraq was similarly ineffective. ${ }^{43}$ In these cases, IF were largely distrusted by the incumbents and were therefore never deployed as the main strategic tool of the COIN operation. Gortzak's analysis of the French-led IF during the Algerian campaign reached similar conclusions. ${ }^{44}$

\section{$40 \quad$ Cassidy, Regular and Irregular.}

${ }^{41}$ Aziz A. Hakimi, 'Getting savages to fight barbarians: counterinsurgency and the remaking of Afghanistan', Central Asian Survey 32/3 (2013) 388-405, 388.

42 Dorronsoro and Lobato, The Militia in Afghanistan.

43 Ahmed S. Hashim, Insurgency and Counter-Insurgency in Iraq (Ithaca: Cornell University Press 2006).

$44 \quad$ Gortzak, Using Indigenous Forces. 
In contrast, the use of IF on a larger scale in American COIN operations during the Philippine-American War and British COIN during the Malayan conflict, as well as much earlier deployment of large IF-manned armies during the British colonial wars on the Indian subcontinent, have proven more successful. ${ }^{45}$ For example, as described by Cassidy, during the American campaign in Vietnam (1965-73), the US military succeeded in raising an army of '50,000 tribal fighters to operate in some of the most austere terrain. ${ }^{46}$ As a result of this mass scale deployment of local forces, which, in addition to indigenous fighters also included former Viet Cong guerrillas, the IF 'worked somewhat effectively and offered the additional value of unhinging the enemy morally and psychologically. ${ }^{, 47}$ In contrast to the deployment of IF at later stages of the conflict in Afghanistan (2003-10), the use of Northern Alliance militias in ousting the Taliban over the course of the early phase of the Afghan campaign yielded positive results. In Somalia, current attempts to use large numbers of indigenous forces to defeat Al-Shabaab militants have thus far proven effective. ${ }^{48}$ In Chechnya, the deployment of indigenous

45 Timothy K. Deady, Lessons from a Successful Counterinsurgency: The Philippines, 1899-1902 (Carlisle: U.S. Army War College 2005); Corum, Training Indigenous Forces; Christopher Herbert, War of No Pity: The Indian mutiny and Victorian Trauma (NJ: Princeton University Press 2008).

46 Cassidy, The Long Small War, 59.

$47 \quad$ Ibid.

48 Jeffrey Gettleman, Mark Mazzetti and Eric Schmitt, 'U.S. Relies on Contractors in Somalia Conflict', New York Times August 10 (2011). 
paramilitaries, as will be demonstrated in this article, contributed to the considerable weakening of the local insurgent force.

The role of asymmetry of values in these conflicts, however, remains unexplored. It remains to be seen why, and under what conditions, IF succeed in turning the tide in an asymmetric conflict. What is known, however, is that in most of the previously mentioned conflicts, honour-based socio-cultural codes deeply engrained in the local cultures create an asymmetry of values observable between local combatants and incumbent forces. As this study demonstrates, the use of IF is associated with the asymmetry of values, and it is through that interplay that local kadyrovtsy units in Chechnya have managed to change the imbalance of values between Russian forces and Chechen rebels, thereby contributing to the conflict's transformation in favour of the incumbent.

\section{The making of a local ally: Kadyrovtsy and pro-Moscow Chechen authorities}

Despite important differences between the two conflicts, the First (1994-96) and Second (1999-ongoing) Chechen wars have an important similarity. Having won the initial, rather conventional phase of the war, the Russian army largely failed to achieve a clearcut victory in the guerrilla phase that ensued. More than four years into the second round of military confrontation and in spite of all its military superiority, the 100,000-strong Russian military in Chechnya still faced a committed insurgent force. A force which, notwithstanding sufficient blows inflicted upon it, the Russian military proved incapable of defeating. Indeed, as late as in 2004, a Russian combat general reported from the republic that the federal troops were 'so busy just trying to ensure their own security' that 
they 'almost never can counter the resurgent guerrillas,' a state of affairs that strikingly resembled the first war. ${ }^{49}$

The situation began to change dramatically only around 2005. At that time, the paramilitary units of Chechnya's pro-Moscow government, kadyrovtsy - named after their commanders Akhmad Kadyrov and his younger son Ramzan - started to be increasingly deployed in combat against insurgent units, gradually replacing the Russian military as the main COIN force. ${ }^{50}$ A number of factors contributed to the establishment of the pro-Moscow Chechen authorities and, most importantly, to the forming of a vicious yet effective indigenous paramilitary force. It is a well-known fact that it was the strategic calculation of Vladimir Putin, Russia's newly elected president and former intelligence officer, to break the backbone of the Chechen insurgency from the inside that prompted him in 2000 to enlist Akhmad Kadyrov, a former insurgent leader. As Putin eloquently put it at the time, 'his [Kadyrov's] contacts with the people who are still putting up resistance against us in Chechnya [...] will be positive. ${ }^{51}$ What is less known about Kadyrov's fundamental incentive to join - and eventually lead - the newly formed pro-Moscow authorities and paramilitary force, was the state of blood feud between him and his enemies among Chechnya's jihadists, an increasingly potent force in the Chechen

49 Mark Kramer, 'The Perils of Counterinsurgency: Russia's War in Chechnya', International Security 29/3 (2004) 5-63, 9.

50 The beginning of the massive deployment of kadyrovtsy paramilitaries in combat dates back to 2003 .

$51 \quad$ Ilya Maksakov, 'Chetyre Putinskikh Goda v Chechne', Prague Watchdog March 26 (2004). 
insurgency movement that Kadyrov's clan seemed incapable of resisting. ${ }^{52}$ From the moment the blood feud was initiated, Kadyrov had to seek collaboration with, and the backing of, the invading Russian forces in order for him and his relatives to survive. Frequently cited ideological considerations, such as Kadyrov's infamous notoriety among Salafis as a devout Sufi - which commentators both in and outside of Russia have often referred to as Kadyrov's sole motive to defect to the Russians - therefore played only a secondary role.

It was against this background that Kadyrov became the main instrument of Moscow's COIN strategy in Chechnya as he used his authority, knowledge, and contacts in the insurgency movement to coerce former insurgents into demobilisation or straightforward defection. Two mechanisms proved particularly effective in this regard. First, initially with the assistance of the Russian military, insurgents were threatened with the targeting of relatives unless they capitulated. Many insurgents submitted to this pressure, while those who resisted saw their relatives tortured and murdered. ${ }^{53}$ 52 In May 1999, just a few months before the outbreak of the Second Chechen War, the animosity between Kadyrov and his opponents among Chechnya's jihadists, led by influential warlords (Shamil Basayev and emir Khattab) resulted in an unsuccessful assassination attempt on Akhmad Kadyrov, which claimed the lives of five of his bodyguards, including three of his nephews. This effectively started the blood feud between the warring sides.

53 The seizure of relatives of Aslan Maskhadov, the leader of Chechnya's insurgency, including his two brothers and sisters aged 69-75, is a typical example of this phenomenon. After Maskhadov's refusal to capitulate, some of his relatives, captured by kadyrovtsy and Russian secret services, disappeared without a trace (Pravda.ru, 'V Chechne Pokhischeny Rodstvenniki Maskhadova', Pravda, January 10 (2005)). 
Remarkably, the deployment of former insurgents, now members of kadyrovtsy units, in insurgent operations helped enhance the incumbent's knowledge of the insurgents' social background and their modus operandi. As early as in 2000, the Russian military launched waves of mop-up operations, infamously known as zachistkas. Encircling entire Chechen villages and neighbourhoods, Russian troops deployed indiscriminate violence en masse. This included extrajudicial killings, torturing, and injuring Chechen males of conscription age on the basis of their alleged participation in insurgent units, as well as terrorising the local population at large. In addition, thousands of Chechen males underwent what came to be known as forced disappearances. Dozens of mass graves were found across Chechnya, containing the bodies of thousands of predominantly young Chechens, most of them bearing signs of torture ${ }^{54}$ Cases of rape were also reported. ${ }^{55}$

For many young Chechens and their families, the only way to survive was through their relatives' membership in the newly formed pro-Moscow paramilitary units. In fact, Irina Gordienko, a Russian liberal journalist who has covered the war from the ground, recalls that, 'it was the membership in kadyrovtsy units alone that ensured Chechen males and their families' safety in the face of violence perpetrated by Russian forces and kadyrovtsy paramilitaries. ${ }^{56}$ In spite of the dishonour resulting from

54 Jamestown Foundation, Chechnya Weekly 8/21 (May 24 2007); The New York Times, 'Russia: Chechen Mass Grave Found', NYT June 21 (2008).

55 For a detailed account of the Russian military-led COIN in Chechnya, see, for instance, Emma Gilligan, Terror in Chechnya: Russia and the Tragedy of Civilians in War (NJ: Princeton University Press 2013).

56 Online interview with Irina Gordienko, Novaya gazeta, 9 June 2014. 
collaboration with the incumbent, thousands of Chechens entered, or were forced to enter under death threats for both themselves and their relatives, into kadyrovtsy units. Once deployed in combat against insurgents, their relatives, and supporters, new recruits found themselves in a no-exit situation, as they were fully engaged in blood feuds with fellow Chechens. They therefore had to rely even more on their relatives and fellow kadyrovtsy to ensure physical survival for themselves and their relatives - resulting in a point of no return.

Four years later, in 2009, the 'anti-terrorist operation' was formally terminated by Moscow, with most Russian troops withdrawn from the erstwhile breakaway republic. Since then, Chechnya has been among the most secure areas of the North Caucasus, with insurgent activity gradually declining. As of 2013, only 39 deaths and 62 injuries were reported as a result of insurgent activity - a tiny fraction of the insurgency-related casualties that had plagued Chechnya in previous years. ${ }^{57}$ In comparison, that same year, the neighbouring republic of Dagestan had 341 deaths and 305 injuries reported as a result of insurgency-related activity. ${ }^{58}$ The seismic shift in insurgent activity has been so significant that, since the late 2000s, Chechnya has been replaced by Dagestan, and episodically also by certain other North Caucasian republics, as the hotbed of insurgent violence. The subsequent chapters outline the particular mechanisms that enabled the incumbent to gradually stem the tide of a once-formidable insurgency in Chechnya.

57 Kavkaz Uzel, January 28 (2014), retrieved from: http://www.kavkazuzel.ru/articles/237203/.

58 Ibid., retrieved from: http://www.kavkaz-uzel.ru/articles/237341/. 


\section{Retaliation}

Together with the code of retaliation, Chechnya's clan-based society has historically facilitated effective mobilisation of clan members to defend their individual honour, as well as that of their kin and clan as a whole. The very concept of blood feud is deeply engrained in Chechnya's clan system, to the extent that retaliation is directed not only at the direct culprit of an offence, but also at his patrilineal male relatives, which has been justified on the grounds of an individuals close ties with his clan-defined relatives. Failure to retaliate, regardless of the circumstances surrounding such decision, result in the offended individual's considerable decline in social status. Notably, this is not confined to individuals, but rather encompasses their entire clan, and results in their public labelling as weaklings and cowards incapable of defending their honour. Ostracism and opprobrium have resulted not only from cases of non-retaliation, but also from an individual's failure to follow the local code of honour encompassing, among other things, the codes of hospitality and silence. ${ }^{59}$

Over the course of the First Chechen War, the profound need to retaliate against the wrongs inflicted upon individuals and their relatives became a key incentive to mobilise. A number of accounts testify to the (initially) apolitical motivation of thousands of ordinary Chechens to go to war just weeks and months following the Russian incursion

59 For a more detailed overview of Chechen ethnography, see Amjad Jaimoukha, The Chechens. A Handbook (NY: Routledge 2005); Emil Souleimanov, An Endless War: The Russian-Chechen Conflict in Perspective (Peter Lang 2007) 19-42. 
into their homeland. ${ }^{60}$ Remarkably, a significant number of Chechens had previously been sceptical of Chechnya's separatist leadership, wishing instead to avoid the mounting hostilities. The excessive use of indiscriminate violence exerted by Russian troops, however, quickly alienated many Chechens, urging them to take up arms in order to restore what they considered to be their (and their relatives') violated honour and dignity. According to an interview with a former insurgent,

In the beginning, no one was really willing to go to war... After all, we all had families, households, elderly parents to care for. But when your younger brother is killed in an air strike, what are you supposed to do? To stay home and watch TV? For us as Chechens, there was no other way left but to take up arms and seek revenge. ${ }^{61}$

\footnotetext{
60 James Hughes, 'The Chechnya Conflict: Freedom Fighters or Terrorists?', Demokratizatsiya 15/3 (2007) 293-311; Souleimanov, An Endless War; Michael McCullough, Beyond Revenge: The Evolution of the Forgiveness Instinct (San Francisco: Jossey-Bass 2008) 35-38; Jean-François Ratelle, Radical Islam and the Chechen War Spillover: A Political Ethnographic Reassessment of the Upsurge of Violence in the North Caucasus since 2009 (University of Ottawa 2013) 157-164.

61 Interview with 'Idris', 43, London, November 2011.
} 
As reinforced by numerous interviews, the need to retaliate was dictated by the local socio-cultural code of honour as an immense moral obligation devoid of ideological, political, or social connotations. ${ }^{62}$

The custom of blood feud has historically been implemented in a highly selective way, as an offended individual or their relatives sought retaliation against a group of males associated with the perpetrator by means of kinship. The anonymity inherent in armed conflict and the offended individual's inability to identify the direct culprit or his relatives from among Russian troops has therefore widened the circle of potential culprits to encompass the entire Russian armed forces. This altered the traditional rules of blood feud and legitimised retaliation against randomly selected Russian combatants. As a consequence, attacks on Russians as an ethnic community also became legitimised as the imaginary border between combatants and Russian society as a whole became increasingly blurred. An individual's inability to identify the direct perpetrator of an offence often prompted them to remain in an insurgent group after retaliation was carried out, thereby contributing to the gradual merger of personal and ideological (nationalistic, political, and religious) motivations. ${ }^{63}$

The code of retaliation has thus been an effective trigger for mobilisation, ensuring a constant inflow of new recruits into the insurgency. Importantly, the structure of Chechnya's clan system has had a snowball effect on individual retaliation, leading

62 Interviews with Chechens, eyewitnesses of the First and Second Chechen wars, in Moscow (September 2009), Paris (August 2011), London (November 2011), and Istanbul (September 2012).

63 Ibid. 
several males to mobilise in order to retaliate against the wrongs and losses suffered by their families and clan members. It is fair to say that Russian troops' indiscriminate targeting of thousands of Chechens has at various stages of military confrontation mobilised an insurgency of thousands of inflicted individuals' relatives, with the murder and particularly rape of one Chechen triggering the mobilisation of an average of three to five male relatives. Remarkably, this mechanism has worked irrespective of an individual's previous political preferences, as many of them reportedly held either antiregime or even anti-separatist views, or distanced themselves from politics entirely. The need to retaliate, as dictated by the local socio-cultural codes and necessitated by public opinion, worked as an apolitical but effective mechanism ensuring mobilisation into the insurgency.

The gradual deployment of thousands of kadyrovtsy in COIN operations from the early 2000s onward has shaken the foundations of Chechen society. Freshly recruited members of the pro-Moscow Chechen paramilitaries, including both former insurgents and Chechen males without previous insurgent experience, have been widely deployed not only in combat against insurgents, but have also been deployed in retributive campaigns against the relatives of actual or alleged insurgents as well as against their supporters - a move aiming to cement the loyalty and devotion of fresh recruits to the proMoscow camp. ${ }^{64}$ As a result of the local tradition of blood feud, thousands of ordinary Chechens - relatives of kadyrovtsy and pro-Moscow authorities - have found themselves

\footnotetext{
64 Interview with a member of the Chechen Ministry of Interior, Istanbul, September 2012. See also Emil Souleimanov, "Russian Chechnya Policy: "Chechenisation" turning into "Kadyrovisation"”, CACI Analyst 5/31 (2006).
} 
in the midst of blood feud with insurgents and their family members. ${ }^{65}$ Since the early 2000s, this has compelled them to join kadyrovtsy units, establish self-defence units in their native villages to repel insurgent attacks, or assist kadyrovtsy paramilitaries in local COIN operations. As may be expected, pro-Moscow Chechens' superior knowledge of their fellow Chechens has reduced the number of those Chechens willing to join the insurgency movement, which would inevitably put their relatives' lives at immense risk.

A key factor behind recruitment into kadyrovtsy and village self-defence units has been the commitment of kadyrovtsy's relatives to retaliate against the insurgents and their relatives. According to an interviewee,

Those Chechens whose relatives found themselves trapped in kadyrovtsy units [...] It was quite natural that they had to defend themselves, to defend their honour. Even if they had sympathised with the fighters [boeviki], they still had to do what they ought to do as Chechens. ${ }^{66}$

This statement emphasises yet again that honour and survival have been stronger motives for violent engagement than political preferences or a desire to avoid the hostilities. As previously mentioned, for those Chechens seeking to retaliate against Russian troops during the First Chechen War as well as during the initial years of the Second Chechen War, the target of retaliation became blurred to encompass the entire Russian armed

65 Emil Souleimanov, 'An Ethnography of Counterinsurgency: Kadyrovtsy and Russia's Policy of Chechenisation', Post-Soviet Affairs, (forthcoming in 2014) 1-24.

66 Interview with 'Rasul', 41, London, November 2011. 
forces. Since the deployment of kadyrovtsy in the COIN operation, the situation has reversed considerably. While kadyrovtsy have often sought to mask their identities during forced disappearances, extrajudicial executions, torture, and rape, individuals seeking retaliation have usually managed to reveal the culprits' identities. In this regard, Mairbek Vatchagaev, a Chechen historian and political scientist, eloquently terms Chechnya - an autonomous republic of slightly more than one million predominantly rural inhabitants - a 'big village', where people know each other and readily find out about others' activities. ${ }^{67}$ Indeed, an individual's membership in a kadyrovtsy unit or deployment in an operation in a particular area has rarely gone unnoticed. As a result, revenge seekers from both sides find it easier to identify and target either the direct perpetrator of an offence or his relatives. The republic therefore quickly entered a vicious state of civil war, with blood feuds tearing apart various Chechen clans.

As in the case of insurgent mobilisation in the First Chechen War, many Chechens (relatives of kadyrovtsy paramilitaries) have joined the ranks of pro-Moscow authorities and forces irrespective of their (initial) political preferences or even in spite of them. As explained by many interviewees, these individuals' motivation to side with the pro-Moscow Chechen camp has often been devoid of any ideological connotations since, as noted by Tomáš Šmíd, 'in these situations, the clan principle is still intact. Since I am one of "us" [kadyrovtsy], I stick to "us." 68 Individual motivation has been dictated rather by more pragmatic considerations than by ideology, whereby individuals seek to attack

\footnotetext{
67 Online interview with Mairbek Vatchagaev, 28 May, 2014.

68 Online interview with Tomáš Šmíd, an expert on the North Caucasus at Masaryk University, 9 June 2014.
} 
the enemy side before it can attack theirs. The code of retaliation has thus ensured constant inflow of recruits into kadyrovtsy paramilitaries in particular and pro-Moscow Chechen armed units in general. With the Russian armed forces' backing on the ground, the (formally) pro-Moscow camp soon gained the upper hand in the conflict, gradually undermining the social base of the insurgency movement.

\section{Code of silence}

The code of silence is deeply rooted in Chechen society, constituting an important component of the local concept of honour. Due to the Chechens' lack of an independent state, centuries of governance and oppression by foreign rulers, the resulting local resistance, and the introverted nature of Chechen clans, local social cultural codes have required clan members to not only avoid any form of collaboration with authorities, but they have also dictated that clans and families avoid disseminating information about their internal issues to outsiders, especially when sensitive information is at stake. Failure to comply with the code of silence leads to ostracism, resulting in a dramatic decrease in individual and collective honour.

In keeping with the code of silence, Chechens largely refused to provide internal information to the Russian military and secret services during the First Chechen War, including information on the identities of insurgents, their supporters, and relatives. In contrast to a number of other (counter)insurgencies elsewhere in the world where locals have often been eager to supply incumbents with information on the insurgents and their social networks in an attempt to obtain benefits, the Chechens stubbornly resisted dragging outsiders into what they considered to be their own internal issues. As one 
interviewee observed, 'on many occasions, the Russian officers approached us offering various things... Money, cattle, security $[\ldots]$ in exchange for information about the fighters. Naturally, we refused, because it's not a Chechen habit to rat on your people. ${ }^{69}$ According to various sources, this has held true even against the background of enormous pressure exerted by authorities on the locals. ${ }^{70}$ Notwithstanding (the threat of) torture, murder, and injury, the overwhelming majority of Chechens chose not to collaborate with the occupiers, a fact that has also been confirmed by Russian sources. ${ }^{71}$ In fact, only a small number of Chechens - mostly the so-called Moscow Chechens, or former communist nomenklatura, located in the republic's Russified northern lowlands - chose to collaborate with the Russian authorities, thereby breaking the local code of honour. Importantly, most interviewees have pointed to the incompatibility between collaboration with Russian forces and the local honour-based code of silence, the opprobrium that may result from such collaboration, and the fear of physical harm at the hands of insurgents as the main impediments to collaborating with authorities. ${ }^{72}$

As a result of failing to penetrate Chechnya's social fabric, the Russian military and secret services found themselves incapable of obtaining highly personalised information from the ground. During the First Chechen War, this effectively prohibited

69 Interview with 'Magomed', 61, Istanbul, September 2012.

70 Interviews with Chechen eyewitnesses of the First Chechen War, in Moscow (September 2009), Paris (August 2011), London (November 2011), and Istanbul (September 2012).

71 Interview with Boris Yemelin, a Russian Army officer during the First Chechen War, Moscow, September 2009.

72 Interviews with Chechen eyewitnesses of the First Chechn War, in Moscow (September 2009), Paris (August 2011), London (November 2011), and Istanbul (September 2012). 
the use of selective violence by the incumbent - a crucial determinant of success in COIN. The Russian military therefore had to rely even more on the use of rather counterproductive indiscriminate violence, thereby helping to fuel the insurgency with thousands of new recruits. At the same time, confidence in the local population's loyalty and non-collaboration with the incumbent forces enabled insurgents to move relatively freely across Chechnya and to carry out covert attacks against Russian troops without the fear of detection or betrayal.

The deployment of kadyrovtsy in combat as well as the increasing number of supporters from among their civilian relatives has had serious implications for how the code of silence has been applied in the Second Chechen War. Engulfed in blood feuds with insurgents and their relatives, the relatives of kadyrovtsy have found themselves at the epicentre of a merciless civil war, a war in which their very physical survival and honour have been contingent upon the pro-Moscow camp's success in COIN operations. Relatives of kadyrovtsy and Chechen authorities alike have begun to provide information about insurgents, their relatives, and supporters inasmuch as this type of information has ceased to be a Chechen internal affair. As noted by an interviewee, 'all of a sudden, ordinary Chechens started ratting on their blood enemies as they became personally involved in the war. ${ }^{73}$ Indeed, in Chechnya's small mountainous villages - the traditional stronghold of the insurgency - an individual's activities are not easily hidden from the rest of the community. Easily detected against the backdrop of isolated mountain communities, a fellow villager's contact with or provision of support to insurgents 'have

73 Interview with 'Magomed', 46, Copenhagen, September 2012. 
now been routinely reported by the relatives of pro-Moscow Chechens. ${ }^{74}$ The disappearance of a Chechen male from his village usually evokes suspicion amongst fellow villagers from the pro-Moscow camp, who in turn inform pro-Moscow Chechen authorities of any such activity. This has resulted in retributive assaults on insurgents' (alleged) supporters or families perpetrated by kadyrovtsy and their local backers, sparking bloody confrontation among the warring camps within particular communities. Due to the numerical superiority of kadyrovtsy and their backing by Russian troops, these confrontations have usually ended in the defeat of pro-insurgent individuals and clans, resulting in the murder or disappearance of the males (and sometimes even females) of entire families and clans. ${ }^{75}$

As testified by numerous interviewees, Chechens largely maintained the code of silence at the beginning of the de facto Chechen civil war. Rather than provide information directly to either federal or Chechen pro-Moscow authorities, many Chechens, particularly from the more conservative rural areas, sought to contact proMoscow Chechen relatives in order to ensure that outsiders were not dragged into what they considered to be their internal affairs. ${ }^{76}$

Over time, the once-omnipresent code of silence has been partially broken, providing pro-Moscow Chechen authorities and law enforcement agencies with access to

\footnotetext{
$74 \quad$ Online interview with Irina Gordienko, Novaya gazeta, 9 June 2014.

75 Kadyrovtsy are a committed, disciplined, and well-armed force of 7,000, outweighing any Chechen clan.

76 Interviews with Chechen eyewitnesses of the First Chechen War, in Moscow (September 2009), Paris (August 2011), London (November 2011), and Istanbul (September 2012).
} 
highly personalised information from Chechen communities. Armed with local knowledge of the insurgents' social base, selective violence perpetrated by kadyrovtsy has become widespread. This, in turn, has enabled incumbent forces to target only insurgents, their supporters, and relatives, while avoiding uninvolved individuals. This has helped to avoid the alienation of masses of uninvolved Chechens - a previous consequence of the largely indiscriminate use of violence by Russian troops in both wars.

\section{Code of hospitality}

An integral part of the local code of honour, hospitality has historically been treated as sacred in Chechen society. Such is the extent of the role of hospitality in Chechen culture that it has been prioritised even above retaliation. According to local customary law, a host is expected to provide even his blood enemy with not only absolute safety, but also shelter and protection from external threats. While strict adherence to customary law has faded somewhat in recent decades, the hospitality-based obligation to provide fellow Chechens, fighters, and all those in need, with any necessary accommodation and material support persists in Chechen society.

During the First Chechen War, insurgents were routinely provided with a broad spectrum of material support by the local population, including food, shelter, warm clothing, medicine, weapons, and ammunition. They would also often provide insurgents with information on the movements and activities of Russian troops stationed nearby. ${ }^{77}$ Interviewees have asserted that their support was clearly mandated by the local code of

77 Online interview with Magomed Toriyev, Radio Freedom/Radio Free Europe, North Caucasian Department, 15 June, 2014. 
hospitality, and was given in spite of the threat of discovery and penalisation by Russian troops. One interviewee has testified to this, observing that, "nokhchalla ${ }^{78}$ required that we not only embraced them [insurgents], but that we also provided them with any necessary support since they were Chechens, Muslims, as we were [...]. ${ }^{79}$ The adatbased support for insurgents was so strong that, in some instances, locals pretended to have provided hospitality to insurgents, such that 'a Chechen who did not aid fighters [boeviki] would lie that he had hosted a group of fighters in the night $[\ldots] .{ }^{80}$ Against this background, the uniform applicability of the code of silence in Chechen society reduced the risk that an individual practicing the code would be revealed as having provided support to insurgents during the First Chechen War.

The implementation of the code of hospitality shaped the social base of the Chechen insurgency to a large extent during the First Chechen War. As an insurgency rises and falls on the tide of popular support, the locals' commitment to providing tangible support to insurgents, dictated by the code of hospitality, enhanced the Chechen insurgents' social mobility in that food, shelter, medicine, and other forms of support were provided to them by the local population in various parts of the republic. This occurred in spite of serious risks for those involved in pro-insurgent activities.

During the Second Chechen War, the incumbent's access to internal information on the ground and its ability to target individuals selectively has undermined the onceuniform applicability of the code of hospitality in Chechen society. Although many

78 Literally translated as 'Chechenness', the code of etiquette interlinked with adat.

79 Interview with 'Musa', 57, London, November 2011.

80 Online interview with Mairbek Vatchagaev, Jamestown Foundation, June 9, 2014. 
Chechens, bound by these socio-cultural codes, have still continued to provide support to the insurgents, the understanding of the high costs of pro-insurgent activity has prompted many Chechens to disassociate themselves from the insurgency - even at the cost of violating the local code of hospitality. 'The danger is just too high now,' admits an interviewee, pointing to the fact that while 'hiding that you aided insurgents in the First [Chechen] War was an easier task' due to the archaic code of silence practiced uniformly among the Chechens, 'nowadays [during the Second Chechen War], there would always be some collaborators in the village that would readily denounce it. ${ }^{81}$ Similarly, Vatchagaev notes that the current system of oppression and retribution imposed by kadyrovtsy has shaken the traditional Chechen codes of, inter alia, hospitality, noting, 'it is not that people refusing support to fighters refuse a life in a free society [devoid of occupation], but that they are afraid of being killed. ${ }^{82}$

Still, even against the backdrop of enormous penalisation, the code of silence has not vanished entirely. Those who in spite of the risks have still continued to provide support to insurgents dramatically reduced the scope of their support, confining it to food, medicine, and warm clothing. Insurgents have typically sought to stay away from villages where they have had supporters in order to either avoid jeopardising the lives of their supporters (and thus lose their support base), or to avoid being captured. Without the shelter and basic medical treatment previously provided to them in towns and villages, insurgents have been forced to spend cold winters up in their mountainous hideouts, frequently moving from place to place. This has understandably significantly weakened

81 Interview with 'Beslan', 60, Copenhagen, September 2012.

82 Online interview with Mairbek Vatchagaev, 9 June 2014. 
their physical and psychological state and has also caused their numbers to decrease due to the shortage of supplies. Unable to uniformly rely on the code of hospitality, the insurgents' ability to move freely across the republic has also been greatly restricted. The polarisation of Chechen society and the emergence of a highly motivated anti-insurgent camp have likewise led to the momentous fragmentation of popular support to the insurgents. Therefore, Chechen insurgency has weakened considerably.

\section{Conclusion}

This article has examined how the deployment of indigenous forces by incumbents can reverse the course of asymmetric conflict, reversing the initial imbalance of socio-cultural values enjoyed by insurgents and thus transforming the conflict dynamics in favour of the incumbent. While the importance of IF in counterinsurgencies has been reiterated in numerous studies, there has been little understanding of the specific mechanisms on the ground allowing IF to contribute to a successful COIN. In order to address this lack of certainty, this article conducted a comprehensive empirical examination of the role of socio-cultural codes in COIN. It particularly examined the code of retaliation as a mechanism of violent mobilisation and the codes of silence and hospitality as insurgent support structures during the First and Second Chechen wars.

This study has also demonstrated that the successful deployment of kadyrovtsy paramilitaries by the incumbent during the second Chechen campaign allowed counterinsurgents to negate the advantages enjoyed by insurgents relying on sociocultural codes during the First Chechen War. Our findings indicate that it is only after the deployment of IF that incumbents have taken advantage of the mechanism of violent 
mobilisation among the local population dictated by the socio-cultural obligation to retaliate against the insurgents, and that this deployment of IF has significantly reduced the insurgents' chances of relying on popular support maintained under the codes of silence and hospitality. As any insurgency is vitally dependent on local support, the use of pro-incumbent IF has left the Chechen insurgency weakened, distanced from the local population and, as a result, devoid of uniform popular support. This proves that the deployment of IF that are both effective and loyal to the incumbent may change the imbalance of socio-cultural values that otherwise work to the insurgents' advantage in favour of the incumbent.

\section{Bibliography}

Abu-Lughod, 1., 'Honor and the Sentiments of Loss in a Bedouin Society', American Ethnologist 12/2 (1985) 245-261.

Arrequin-Toft, I., 'How the Weak Win Wars. A Theory of Asymmetric Conflict', International Security 26/1 (2001) 93-128.

Ballentine, K. and Sherman, J., The Political Economy of Armed Conflict: Beyond Greed and Grievance (Boulder: Lynne Rienner 2003).

Bell, R., Fate, Honor, Family and Village. Demographic and Cultural Change in Rural Italy since 1800 (Chicago: Chicago University Press 2009).

Berman, E., Shapiro J. and Felter, J., 'Can Hearts and Minds Be Bought? The Economics of Counterinsurgency in Iraq', Journal of Political Economy 119/4 (2011) 766-819. 
Boehm, C., Blood Revenge. The Enactment and Management of Conflict in Montenegro and other tribal societies (Lawrence: University Press of Kansas 1984).

Boyle, M., 'Revenge and reprisal violence in Kosovo', Conflict, Security \& Development 10/2, (2010) 189-216.

Buffaloe, D., 'Defining Asymmetric Warfare', The Land Warfare Papers 58 (2006) 2224.

Cassidy, R., 'Back to the Street without Joy: Counterinsurgency Lessons from Vietnam and Other Small Wars', Parameters (2004) 73-83.

Cassidy, R., 'Counterinsurgency and Military Culture: State Regulars versus Non-State Irregulars', Baltic Security \& Defence Review 10 (2008) 53-85.

Cassidy, R., 'Regular and Irregular Indigenous Forces for a Long Irregular War', The RUSI Journal, 152 /1 (2007) 42-47.

Cassidy, R., 'The Long Small War: Indigenous Forces for Counterinsurgency', Parameters (2006) 47-62.

Cassidy, R., 'Why Great Powers Fight Small Wars Badly', Military Review (2000) 41-53.

Cassidy, R., Russia in Afghanistan and Chechnya: Military Strategic Culture and the Paradoxes of Asymmetric Conflict (PA: Strategic Studies Institute 1993).

Corum, J., Training Indigenous Forces in Counterinsurgency: A Tale of Two Insurgencies (PA: Strategic Studies Institute 2006).

Deady, T., Lessons from a Successful Counterinsurgency: The Philippines, 1899-1902 (Carlisle: U.S. Army War College 2005).

Dorronsoro, G. and Lobato, C., 'The Militia in Afghanistan', Central Asian Survey 8/4 (1989) 95-108. 
Fischerkeller, M., 'David versus Goliath: Cultural judgments in asymmetric wars', Security Studies 7/4 (1998) 1-43.

Gettleman, J., Mazzetti, M. and Schmitt, E., 'U.S. Relies on Contractors in Somalia Conflict', New York Times August 10 (2011).

Gilligan, E., Terror in Chechnya: Russia and the Tragedy of Civilians in War (NJ: Princeton University Press 2013).

Gortzak, Y., 'Using Indigenous Forces in Counterinsurgency Operations: The French in Algeria, 1954-1962‘, Journal of Strategic Studies, 32/2 (2009) 307-333.

Gould, R., 'Revenge as Sanction and Solidarity Display: An Analysis of Vendettas in Nineteenth-Century Corsica', American Sociological Review 65/5 (2000) 682-704.

Gray, C., 'Thinking Asymmetrically in Times of Terror', Parameters (2002), 5-14.

Gross, M., Moral Dilemmas of Modern War: Torture, Assassination and Blackmail in an Age of Asymmetric Conflict (NY: Cambridge University Press 2010).

Hakimi, A., 'Getting savages to fight barbarians: counterinsurgency and the remaking of Afghanistan', Central Asian Survey 32/3 (2013) 388-405.

Hashim, A., Insurgency and Counter-Insurgency in Iraq (Ithaca: Cornell University Press 2006).

Herbert, C., 2008. War of No Pity: The Indian mutiny and Victorian Trauma (NJ: Princeton University Press).

Hughes, J., 'The Chechnya Conflict: Freedom Fighters or Terrorists?', Demokratizatsiya $15 / 3$ (2007) 293-311.

Ikegami, E., The Taming of the Samurai: Honorific Individualism and the Making of Modern Japan (Cambridge: Harvard University Press 1995). 
Jaimoukha, A., The Chechens. A Handbook (NY: Routledge 2005).

Jamestown Foundation, Chechnya Weekly 8/21 (May 24 2007).

Kaldor, M., New and Old Wars. Organized Violence in a Global Era (Cambridge: Polity Press 2006).

Kilcullen, D., An Accidental Guerilla. Fighting Small Wars in the midst of a Big One (Oxford: Oxford University Press 2009).

Kober, A., 'From Heroic to Postheroic Warfare: Israel's Way of War in Asymmetrical Conflicts', Armed Forces \& Society 0 (2013) 1-27.

Kramer, M., 'The Perils of Counterinsurgency: Russia's War in Chechnya', International Security 29/3 (2004) 5-63, 9.

Lister, C., 'Cultural Awareness and Counterinsurgency in Afghanistan,' E-International Relations 11 (2011) 2.

Luttwak, E., 'Toward Post-Heroic Warfare', Foreign Affairs (May/June 1995).

Mack, A., 'Why Big Nations Lose Small Wars: The Politics of Asymmetric Conflict', World Politics 27/1 (1975).

Maksakov, I., 'Chetyre Putinskikh Goda v Chechne', Prague Watchdog March 26 (2004).

McCullough, M., Beyond Revenge: The Evolution of the Forgiveness Instinct (San Francisco: Jossey-Bass 2008), 35-38.

Merom, G., How Democracies Lose Small Wars. State, Society and the Failures of France in Algeria, Israel in Lebanon and the United States in Vietnam (Cambridge: Cambridge University Press 2003). 
Miakhel, S., Understanding Afghanistan: The Importance of Tribal Culture and Structure in Security and Governance (US Institute of Peace 2009).

Mohamed, J., 'Kinship and Contract in Somali Politics', Africa 77/02 (May 2007) 226249.

Nisbett, R. and Cohen, D., Culture of Honor. The Psychology of Violence in the South (Boulder: Westview Press 1996).

Nivette, A., 'Violence in Non-State Societies. A Review', British Journal of Criminology $51(2011)$ 578-598.

Paul, T.V., Asymmetric Conflicts: War Initiation by Weaker Powers (Cambridge: Cambridge University Press 1994).

Ratelle, J-F., Radical Islam and the Chechen War Spillover: A Political Ethnographic Reassessment of the Upsurge of Violence in the North Caucasus since 2009 (University of Ottawa 2013).

Simon, S., 'Politics and Headhunting among the Formosan Sejiq: Ethnohistorical Perspectives', Oceania 82/2 (2012) 164-185.

Sokirianskaia, E., 'Families and Clans in Ingushetia and Chechnya. A Fieldwork Report', Central Asian Survey 24/4 (2005) 453-67.

Souleimanov, E., 'An Ethnography of Counterinsurgency: Kadyrovtsy and Russia's Policy of Chechenisation', Post-Soviet Affairs, (forthcoming, 2014) 1-24.

Souleimanov, E., 'Russian Chechnya Policy: "Chechenisation" turning into “Kadyrovisation”, CACI Analyst 5/31 (2006).

Souleimanov, E., 'The Caucasus Emirate: Genealogy of an Islamist Insurgency, Middle East Policy 18/4 (2011) 55-168. 
Souleimanov, E., An Endless War: The Russian-Chechen Conflict in Perspective (Peter Lang 2007).

The New York Times, 'Russia: Chechen Mass Grave Found', NYT June 21 (2008).

Theidon, K., 'Transitional Subjects: The Disarmament, Demobilization and Reintegration of Former Combatants in Colombia', The International Journal of Transitional Justice 1 (2007) 66-90.

van Baarda, Th.A. and Verweij, D.E.M., (eds.) The Moral Dimension of Asymmetrical Warfare. Counter-terrorism, Democratic Values and Military Ethics (Leiden: Martinus Nijhof 2009).

Winter, Y., 'The Asymmetric War Discourse and its Moral Economies: A Critique', International Theory 3/3 (2011) 488-514. 